\title{
Methods for Estimating the Volume of the Tympanic Bulla in the Big Hairy Armadillo Chaetophractus villosus (Mammalia, Xenarthra, Dasypodidae)
}

\author{
Métodos para la Estimación del Volumen de Bula Timpánica en el \\ Quirquincho Grande Chaetophractus villosus (Mammalia, Xenarthra, Dasypodidae)
}

Ana Paula Basso ${ }^{1,2}$; Nora Silvia Sidorkewicj ${ }^{1,2}$ \& Emma Beatriz Casanave ${ }^{1,2}$

BASSO, A. P.; SIDORKEWICJ, N. S. \& CASANAVE, E. B. Methods for estimating the volume of the tympanic bulla in the big hairy armadillo Chaetophractus villosus (Mammalia, Xenarthra, Dasypodidae). Int. J. Morphol., 35(1):128-132, 2017.

SUMMARY: Two methods of measurement of bullar dimensions (callipers and scaling from digital images) and subsequent application of four volume formulae (rectangular prism, cylinder, ellipse and elliptical cone) were tested to find the most appropriate non-destructive method for estimating the bullar volume in Chaetophractus villosus. Material for the study consisted in clean adult skull $(n=22)$. Real volume was obtained from latex casts of the tympanic bulla. Each estimation was corrected by a factor based on the differences between the estimated and the real volumes. Highest accuracy (5-7 \% of underestimation) and precision (coefficient of variation: $13.27 \%$ ) were obtained from callipers and application of rectangular prism, cylinder and ellipse formulae. The corresponding correction factors were $0.31,0.39$ and 0.58 , respectively.

KEY WORDS: Fossorial mammals; Armadillos; Middle ear; Auditory bulla; Non-destructive methods.

\section{INTRODUCTION}

The big hairy armadillo Chaetophractus villosus (Desmarest, 1804) belongs to the widespread and diverse dasypodid family, a group of primarily burrowing mammals that dig tunnels for foraging activity, to obtain shelter from predators and climate, and to be used as dens.

In subterranean environments, low frequencies have been shown to be better propagated than higher frequencies (Heth et al., 1986). Therefore, animals under selective pressures in hypogean habitats have developed certain anatomic and physiological auditory specializations that enhance low frequency detection, which may include massive middle ear ossicles, loosening of their ligamentous attachments, large tympanic membranes and increased bullar volumes (Burda et al., 1990, 1992; Webster \& Plassmann, 1992; Mason, 2001, 2004, 2016; Begall \& Burda, 2006; Argyle \& Mason, 2008; Schleich \& Busch, 2004; Francescoli et al., 2012). The latter, which was mainly studied in rodents, has been interpreted as a character with adaptive value within underground tunnels in terms of echolocation (Roig, 1971), vocal communication (Schleich \& Vasallo, 2003; Schleich \& Busch; Francescoli et al.) and detection of predators (Ravicz \& Rosowski, 1997; Schleich \& Vasallo; Francescolli et al.). In dasypodids, the bullae are generally large and inflated, better developed than in any other group of xenarthrans (Roig; Segall, 1976; Patterson et al., 1989; Wible \& Gaudin, 2004), condition that has been suggested as being an adaptation to life not only in underground niches but also in increased eremic conditions (Roig; Squarcia et al., 2007). Notwithstanding, studies that allow comparing bullar volume among the different species of armadillos are scarce, which represents a major shortcoming if taking into account that such knowledge would be a valuable starting point for testing the adaptive value of auditory specializations in the group.

The estimation of the bullar volume by nondestructive methods is not an easy task, owing to its convex shape and, sometimes, to the laboriousness in establishing the exact limits of the bony walls. Some authors have associated the shape of the bulla of different mammalian

\footnotetext{
${ }^{1}$ Departamento de Biología, Biología y Farmacia, Universidad Nacional del Sur (UNS), San Juan 670, 8000 Bahía Blanca, Argentina.

2 Instituto de Ciencias Biológicas y Biomédicas del Sur (INBIOSUR), Consejo Nacional de Investigaciones Científicas y Técnicas (CONICET-UNS). Funded by the Secretaría General de Ciencia y Tecnología (SGCyT), UNS, Project PGI 24/B198.
} 
species to idealised geometric figures in order to calculate the bullar volume from external measurements; such figures include, for example, the cylinder (Lange et al., 2004), the rectangular prism (Huang et al., 2002; Lange \& Burda, 2005), or the elliptical cone (Schleich \& Vassallo; Begall \& Burda; Francescoli et al.). However, a comparison between the different methods employed has never been performed, nor is available a detailed study of the relationship between this type of estimations and the real tympanic volume. The objective of the present work was to evaluate the accuracy and precision of non-destructive methods to estimate the bullar volume in C. villosus.

\section{MATERIAL AND METHOD}

Adult skulls of $C$. villosus $(\mathrm{n}=22)$ were taken from the collection of the Laboratory of Comparative Anatomy (Departamento de Biología, Bioquímica y Farmacia, UNS).

Estimation of the bullar volume (BV). Two non-destructive methods were used to obtain external linear measurements of the tympanic bulla: digital callipers $(0.01 \mathrm{~mm})$ and scaling tool of TPSDig2 software (Rohlf, 2010). In the last case, images were obtained with a digital camera (Panasonic Lumix DMC-TZ5); parallax problems were minimised by taking into account several considerations: i- the camera was fixed at a constant visual distance with the aid of a vertical stand; ii- the material was successively placed in the middle of the visual campus, coordinated on a graph paper between horizontal and vertical lines; iii- all images were captured in one session.

Three parameters were registered with each method (Fig. 1). From the ventral view of the skull, we obtained bullar length (BL, distance between the rostral and caudal maximum convexities of the bulla) and bullar width (BW, perpendicular distance to $\mathrm{BL}$, at the point of the maximum bullar convexity). In lateral view, we registered bullar height (BH, perpendicular length to the plane defined by $\mathrm{BL}$ and $\mathrm{BW}$, measured at the dorsal border of the external acoustic meatus). All measurements were performed in the right bulla, unless it was not correctly preserved.

Measurements were used to estimate the BV by applying the volume formulae for different geometrical figures: rectangular prism $(R P=B L * B W * B H)$, cylinder $(C Y=\pi * B L / 2 * B W / 2 * B H)$, ellipse $(E L=4 \pi / 3 * B L / 2 *$ $B W / 2 * B H / 2)$ and elliptical cone $(C O=[\pi * B L / 2 * B W /$ $2 * B H] / 3$ ). Eight estimations were then obtained, four from callipers $\left(\mathrm{RP}_{\mathrm{C}}, \mathrm{CY}_{\mathrm{C}}, \mathrm{EL}_{\mathrm{C}}, \mathrm{CO}_{\mathrm{C}}\right)$ and four from digital images $\left(\mathrm{RP}_{\mathrm{D}}, \mathrm{CY}_{\mathrm{D}}, \mathrm{EL}_{\mathrm{D}}, \mathrm{CO}_{\mathrm{D}}\right)$.
Determination of the real BV (RBV). After the registration of parameters were completed, the ventral wall of the bulla was sectioned by means of a dental lab drill (16000 RPM, $1 / 4 \mathrm{HP}$ ) to obtain two bullar halves (dorsal and ventral). Middle ear ossicles were carefully removed. External acoustic meatus was sealed with epoxy mastic $\left(\right.$ POXILINA $^{\circledR}$ ), whereas tiny holes (oval and round windows, small fissures, etc.) were sealed with a fast-drying product $\left(\right.$ POXIMIX $^{\circledR}$ ). Both halves of the bulla were then filled with liquid pre-vulcanized natural latex (REVULTEX MR), dyed with a small amount of artificial colorant; this procedure was performed slowly with the aid of a syringe $\left(0.1 \mathrm{~mm}^{3}\right)$ to avoid the formation of air bubbles. Owing to the contraction that occurs in the latex during its drying, the bony halves were refilled as many times as necessary to achieve complete filling. After $43 \mathrm{~h}$ from the beginning of the filling process, the casts were removed and weighed in a digital balance (O’Haus PA313; 0.001g). Latex density $\left(0.95 \mathrm{~g} \mathrm{~cm}^{-}\right.$ ${ }^{3}$ ) was used to make the conversion from weight to volume; to know the change in mass that occurs during the solidification of the product owing to water evaporation, a known quantity of it was weighed at liquid state and weighed again after $43 \mathrm{~h}$. The change in density caused by the addition of the artificial colorant was considered negligible.

For each specimen, the volume of the middle ear ossicles was obtained by the volume of water displaced in a sealed microsyringe, and this value was subtracted from the volume of the corresponding cast to obtain RBV.

Data analysis. Each set of the eight estimations (raw data) was divided into two groups according to the difference between the estimated volume and RBV. In each case, the group with the lowest differences $(n=9)$ was used to calculate a correction factor:

$$
\left(C F=1 / 9 \sum_{i=1}^{9} \frac{R B V i}{B V i}\right)
$$

which was applied over the second group $(n=13)$ to obtain the corrected estimated volume: $\mathrm{CRP}_{\mathrm{C}}, \mathrm{CCY}_{\mathrm{C}}, \mathrm{CEL}_{\mathrm{C}}, \mathrm{CCO}_{\mathrm{C}}$, $\mathrm{CRP}_{\mathrm{D}}, \mathrm{CCY}_{\mathrm{D}}, \mathrm{CEL}_{\mathrm{D}}, \mathrm{CCO}_{\mathrm{D}}$.

Regression analyses were performed between the corrected estimated volumes and RBV $(n=13$ in all cases; Infostat version 1.1, 2006).

\section{RESULTS}

Mean RBV ( \pm S.D.) was $826.1( \pm 113.3) \mathrm{mm}^{3}$. The latex casts, which were easily removed with the aid of dissecting forceps, were predominantly elliptical, with accessory small and spherical masses. The middle ear 


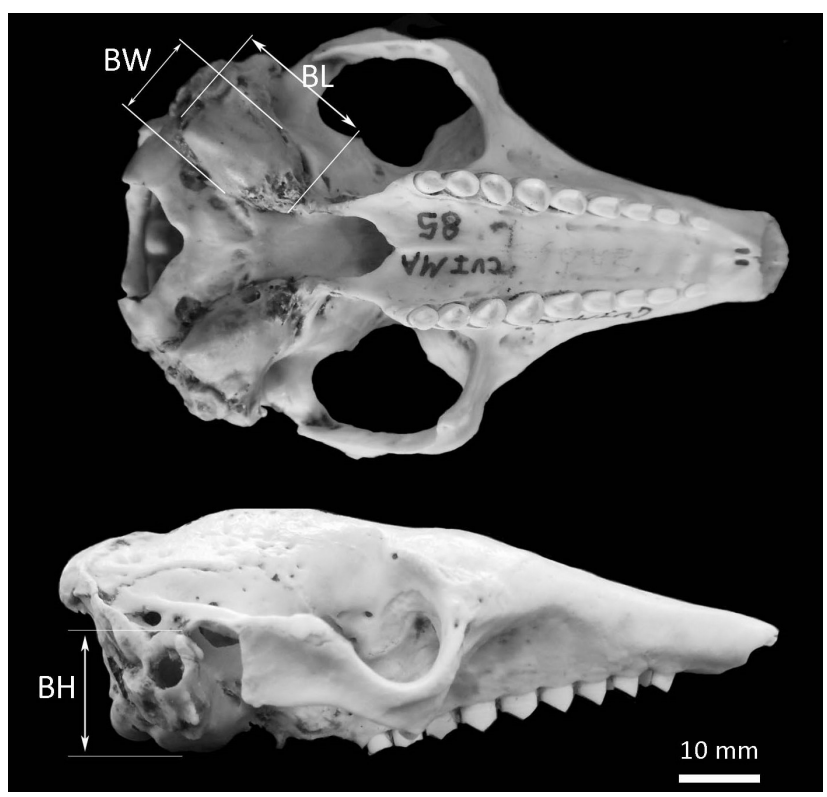

Fig. 1. Ventral (above) and lateral (below) views of the skull of Chaetophractus villosus illustrating the measured parameters. BL: bullar length; BW: bullar width; BH: bullar height.

Table II. Raw $(n=22)$ and corrected $(n=13)$ mean values $\left( \pm\right.$ SD) of the estimated bullar volume $\left(\mathrm{mm}^{3}\right)$ obtained from two different measurement methods and subsequent application of four mathematical formulae. The over $(+)$ and under $(-)$ estimations with respect to the real volume $\left(\mathrm{RBV}=826.1 \mathrm{~mm}^{3}\right)$ are shown between parentheses (bias, \%). The coefficient of variation $(\mathrm{CV}, \%)$ and the determination coefficients corresponding to the corrected volume-RBV relationships $\left(\mathrm{R}^{2}\right)$ are also indicated. CF: correction factor applied to the raw data to obtain the corrected volume. Other abbreviations: in text.

\begin{tabular}{|c|c|c|c|}
\hline & & Callipers & Digital images \\
\hline \multirow{7}{*}{$\begin{array}{l}\text { Rectangular } \\
\text { prism(RP) }\end{array}$} & Raw volume & $\mathbf{R P}_{\mathbf{C}}=2521.6 \pm 334.4$ & $\mathbf{R P}_{\mathbf{D}}=2618.6 \pm 610.0$ \\
\hline & (bias, \%) & $(+205 \%)$ & $(+217 \%)$ \\
\hline & CF & 0.37 & 0.38 \\
\hline & Corrected volume & $\mathbf{C R P}_{\mathbf{C}}=1005.3 \pm 95.4$ & $\mathbf{C R P}_{\mathbf{D}}=1119.0 \pm 216.3$ \\
\hline & (bias, \%) & $(+22 \%)$ & $(+35 \%)$ \\
\hline & CV & 9.49 & 20.24 \\
\hline & $\mathrm{R}^{2}$ & 0.82 & 0.04 \\
\hline \multirow[t]{6}{*}{ Cylinder (CY) } & $\begin{array}{l}\text { Raw volume } \\
\text { (bias, \%) }\end{array}$ & $\begin{aligned} \mathbf{C Y}_{\mathbf{C}}= & 2051.2 \pm 288.7 \\
& (+148 \%)\end{aligned}$ & $\begin{array}{c}\mathbf{C Y}_{\mathbf{D}}=2056.6 \pm 479.1 \\
(+149 \%)\end{array}$ \\
\hline & $\mathrm{CF}$ & 0.47 & 0.49 \\
\hline & Corrected volume & $\mathbf{C C Y}_{\mathbf{C}}=1003.0 \pm 95.2$ & $\mathbf{C C Y}_{\mathbf{D}}=1125.8 \pm 224.6$ \\
\hline & (bias, \%) & $(+21 \%)$ & $(+36 \%)$ \\
\hline & $\mathrm{CV}$ & 9.49 & 19.33 \\
\hline & $\mathrm{R}_{2}$ & 0.82 & 0.09 \\
\hline \multirow[t]{5}{*}{ Ell ipse (EL) } & $\begin{array}{l}\text { Raw volume } \\
\text { (bias, \%) }\end{array}$ & $\begin{array}{c}\mathbf{E L}_{\mathbf{C}}=1367.5 \pm 192.4 \\
(+65 \%)\end{array}$ & $\begin{array}{c}\mathbf{E L}_{\mathbf{D}}=1317.1 \pm 319.1 \\
(+59 \%)\end{array}$ \\
\hline & $\mathrm{CF}$ & 0.71 & 0.74 \\
\hline & $\begin{array}{l}\text { Corrected volume } \\
\text { (bias, \%) }\end{array}$ & $\mathbf{C E L} \mathbf{L}_{\mathbf{C}}=1010.1 \pm 95.9$ & $\mathbf{C E L}_{\mathbf{D}}=1130.9 \pm 228.9$ \\
\hline & $\mathrm{CV}$ & 9.49 & 19.95 \\
\hline & $\mathrm{R}_{2}$ & 0.82 & 0.11 \\
\hline \multirow[t]{6}{*}{$\begin{array}{l}\text { Ell iptical } \\
\text { cone }(\mathrm{CO})\end{array}$} & $\begin{array}{l}\text { Raw volume } \\
\text { (bias, \%) }\end{array}$ & $\begin{array}{c}\mathbf{C O}_{\mathrm{C}}=660.2 \pm 87.5 \\
(-20 \%)\end{array}$ & $\begin{array}{c}\mathbf{C O}_{\mathrm{D}}=685.5 \pm 159.7 \\
(-17 \%)\end{array}$ \\
\hline & $\mathrm{CF}$ & 1.10 & 1.02 \\
\hline & Corrected volume & $\mathbf{C C O}_{\mathbf{C}}=702.9 \pm 114.0$ & $\mathbf{C C O} \mathbf{O}_{\mathbf{D}}=631.5 \pm 121.3$ \\
\hline & (bias, \%) & $(-15 \%)$ & $(-24 \%)$ \\
\hline & CV & 16.22 & 19.21 \\
\hline & $\mathrm{R}^{2}$ & 0.73 & 0.66 \\
\hline
\end{tabular}

Table I. Mean values (mm), standard deviations (SD, mm) and coefficient of variation $(\mathrm{CV}, \%)$ for the bullar dimensions of Chaetophractus villosus.

\begin{tabular}{lcccccc}
\hline & \multicolumn{3}{c}{ Callipers } & \multicolumn{3}{c}{ Digital images } \\
& BL & BW & BH & BL & BW & BH \\
\hline Mean & 14.30 & 10.57 & 16.56 & 15.36 & 10.69 & 15.91 \\
SD & 0.82 & 0.69 & 1.60 & 1.24 & 1.08 & 1.78 \\
CV & 5.76 & 6.56 & 9.67 & 8.07 & 10.10 & 11.19
\end{tabular}

BL: bullar length; BW: bullar width; BH: bullar height.

ossicles represented on average $0.0025 \%$ of the bullar volume.

The parameters registered by means of callipers were more precise than those obtained from digital images (Table I). In both measurement methods $\mathrm{BH}$ was the variable which involved more effort to be obtained and resulted in higher data deviation.

The results from the combination between measurement methods and mathematical formulae used are shown in Table II. Raw data underestimated (CO) or overestimated (RP, CY, EL) the $\mathrm{RBV}$, both from callipers as from digital images; greatest overestimations were observed with RP formula, followed by CY and, in the last place, EL. The values obtained by applying the correction factor generally diminished these biases, and reduction was more marked in $\mathrm{CRP}_{\mathrm{C}}, \mathrm{CCY}_{\mathrm{C}}$ and $\mathrm{CEL}_{\mathrm{C}}$. These estimates were also the most precise, as indicated by the smallest values of coefficient of variation (CV).

The relationships between corrected estimated volumes and RBV were found to be significant only for the estimations based on callipers $(p<0.0002$ in all cases). The four mathematical formulae yielded acceptable values of determination coefficients $\left(\mathrm{R}^{2}\right)$, although $\mathrm{CO}$ presented the lowest one (Table II).

Taking into account that the best outcomes were obtained from 
the combination of callipers and RP, CY and EL formulae, but still resulted in considerable biases $(+21-22 \%)$, new adjusted correction factors (ACF) were calculated as follows: $A C F=(R B V * C F / B V)$, where $\mathrm{BV}$ was $\mathrm{CRP}_{\mathrm{C}}, \mathrm{CCY}_{\mathrm{C}}$ and $\mathrm{CEL}_{\mathrm{C}}$. The values of ACF were $0.31,0.39$ and 0.58 for $\mathrm{CRP}_{\mathrm{C}}$, $\mathrm{CCY}_{\mathrm{C}}$ and $\mathrm{CEL}_{\mathrm{C}}$, respectively, which drastically reduced errors to $-5 \%\left(\mathrm{CRP}_{\mathrm{C}}: 781.7 \pm 103.7\right),-6 \%\left(\mathrm{CCY}_{\mathrm{C}}\right.$ : $772.4 \pm 102.4)$ and $-7 \%\left(\mathrm{CEL}_{\mathrm{C}}: 765.8 \pm 101.6\right)$. Regressions of the new estimated volumes vs. RBV for the whole data $(n=22)$ resulted in low values of $R^{2}(0.57)$ owing to the something higher CV's (13.27) but were highly significant $(\mathrm{p}<0.006)$ in the three cases.

\section{DISCUSSION}

We have tested two methods of measurement of bullar dimensions and subsequent application of different volume formulae to find the most appropriate non-destructive method for estimating BV in C. villosus.

Bullar height $(\mathrm{BH})$ represented the most difficult parameter to register both with callipers as with digital measurements owing that the upper limit of the bulla is not clearly defined in lateral view. On the other hand, its lower limit lies in a deeper plane with respect to the upper one; as a result the callipers did not have a fixed toehold whereas the digital images had logical problems of parallax.

Callipers resulted in more precise estimations of the bullar volume than digital images. Registration of parameters based on digital images appears as a promising tool for creating data files which can be used in future studies. For the tympanic bulla of $C$. villosus, however, it does not seem to be a valid alternative. The markedly rounded shape of the bulla in this species caused, despite the precautions taken during photograph shooting to avoid parallax issues, intrinsic problems that were present not only for $\mathrm{BH}$ but also for parameters taken in ventral view (BL and BW). Since linear measurements were introduced into volumetric formulae, minor variations led to markedly increased data dispersion.

Several authors have determined the BV in different mammalian species from external measurements which were later introduced in mathematical formulae (e.g. Lange et al.; Huang et al.; Lange \& Burda; Schleich \& Vassallo; Begall \& Burda; Francescoli et al.), but the reasons for the election of a determined volume formula were not put forward. In $C$. villosus, in particular, the ellipse seems to be a priori the most adequate expression to be used because is the most assimilable (in external view) to the real shape of the tympanic bulla. However, results showed that similar levels of accuracy and precision were obtained also with the cylinder and the rectangular prism. The elliptical cone was the least appropriate, as indicated by the highest $\mathrm{CV}$ and the lowest $\mathrm{R}^{2}$ values.

The application of a correction factor to the estimated volumes ensured to minimise errors arising from not considering spaces occupied by middle ear ossicles, promontorium, etc., as well as from the possible existing differences between the real shape of the tympanic bulla and the idealised geometric figures considered. The correction factor obtained in this study was precise and robust enough because calculations were based on the least differences between the real and the estimated volume; this was demonstrated by the high $\mathrm{R}^{2}$ obtained when it was applied to another subsample with higher range of RBV-BV differences. However, a considerable bias was still present which was markedly reduced by adjusting calculations, obtaining a new correction factor with good levels of accuracy and precision.

We conclude that the measurement of bullar parameters with callipers, subsequent application of mathematical formulae and correction by a factor can be a valuable alternative to obtain information about the bullar voume in $C$. villosus when destructive methods or computed tomography are not possible prospects. Best results in terms of accuracy and precision were obtained by application of rectangular prism, cylinder and ellipse formulae, with correction factors of $0.31,0.39$ and 0.58 , respectively. The simplicity of the method, which enables to quickly obtain reliable results, makes it an advisable alternative to be tested in other dasypodid species with similar bullar characteristics, previous finding of its own correction factors.

\section{ACKNOWLEDGMENTS}

The authors thank the statistical assistance and the critical revision of the manuscript made by M.V. Lodovichi. Financial support by the Secretaría General de Ciencia y Tecnología, Universidad Nacional del Sur (Project PGI 24/ B198) is greatly acknowledged.

BASSO, A. P. ; SIDORKEWICJ, N. S. \& CASANAVE, E.B. Métodos para la estimación del volumen de bula timpánica en el quirquincho grande Chaetophractus villosus (Mammalia, Xenarthra, Dasypodidae). Int. J. Morphol., 35(1):128-132, 2017.

RESUMEN: Se evaluaron dos métodos para la obtención de medidas de la bula (calibre y escalado a partir de imágenes 
digitales), con posterior aplicación de cuatro fórmulas de volumen (prisma rectangular, cilindro, elipse y cono elíptico), a fin de hallar el método no destructivo más adecuado para el cálculo de volumen de bula en Chaetophractus villosus. El material de estudio consistió en cráneos limpios de individuos adultos ( $\mathrm{n}=22)$. El volumen real fue obtenido a partir de moldes de látex de la bula timpánica. Cada estimación fue corregida mediante un factor basado en las diferencias entre los volúmenes reales y estimados. La mayor precisión (coeficiente de variación: $13,27 \%$ ) y exactitud (subestimaciones del 5-7\%) fueron obtenidas a partir de mediciones con calibre y aplicación de fórmulas de prisma rectangular, cilindro y elipse (factores de corrección: 0,31, 0,39 y 0,58, respectivamente).

PALABRAS CLAVE: Mamíferos fosoriales; Armadillos; Oído medio; Bula auditiva; Métodos no destructivos.

\section{REFERENCES}

Argyle, E. C. \& Mason, M. J. Middle ear structures of Octodon degus (Rodentia: Octodontidae), in comparison with those of subterranean caviomorphs. J. Mammal., 89(6):1447-55, 2008.

Begall, S. \& Burda, H. Acoustic communication and burrow acoustics are reflected in the ear morphology of the coruro (Spalacopus cyanus, Octodontidae), a social fossorial rodent. J. Morphol., 267(3):382-90, 2006.

Burda, H.; Bruns, V. \& Muller, M. Sensory Adaptations in Subterranean Mammals. In: Nevo, E. \& Reig, O. A. (Eds.). Evolution of subterranean mammals at the organismal and molecular levels. New York, WileyLiss, 1990. pp.269-93.

Burda, H.; Bruns, V. \& Hickman, G. C. The ear in subterranean insectivora and rodentia in comparison with ground-dwelling representatives. I. Sound conducting system of the middle ear. J. Morphol., 214(1):4961,1992

Francescoli, G.; Quirici, V. \& Sobrero, R. Patterns of variation in the tympanic bulla of tuco-tucos (Rodentia, Ctenomyidae, Ctenomys). Acta Theriol., 57(2):153-63, 2012.

Heth, G.; Frankenberg, E. \& Nevo, E. Adaptive optimal sound for vocal communication in tunnels of a subterranean mammal (Spalax ehrenbergi). Experientia, 42(11-12):1287-9, 1986.

Huang, G. T.; Rosowski, J. J.; Ravicz, M. E. \& Peake, W. T. Mammalian ear specializations in arid habitats: structural and functional evidence from sand cat (Felis margarita). J. Comp. Physiol. A Neuroethol. Sens. Neural Behav. Physiol., 188(9):663-81, 2002.

InfoStat. Grupo InfoStat, version 1.1. Córdoba, FCA, Universidad Nacional de Córdoba, Argentina, 2006.

Lange, S. \& Burda, H. Comparative and functional morphology of the middle ear in Zambezian mole-rats (Coetomys - Cryptomys, Bathyergidae). Belg. J. Zool., 135 (Supplement):5-10, 2005

Lange, S.; Stalleicken, J. \& Burda, H. Functional morphology of the ear in fossorial rodents, Microtus arvalis and Arvicola terrestris. J. Morphol., 262(3):770-9, 2004.

Mason, M. J. Middle ear structures in fossorial mammals: a comparison with non-fossorial species. J. Zool., 255(4):467-86, 2001.

Mason, M. J. The middle ear apparatus of the tuco-tuco Ctenomys sociabilis (Rodentia, Ctenomyidae). J. Mammal., 85(4):797-805, 2004.

Mason, M. J. Structure and function of the mammalian middle ear. I: Large middle ears in small desert mammals. J. Anat., 228(2):284-99, 2016.

Patterson, B.; Segall, W. \& Turnbull, W. D. The ear region in Xenarthrans (= Edentata: Mammalia). Part I. Cingulates. Fieldiana, Geology, New Ser., No. 18:1-46, 1989.
Ravicz, M. E. \& Rosowski, J. J. Sound-power collection by the auditory periphery of the Mongolian gerbil Meriones unguiculatus: III. Effect of variations in middle-ear volume. J. Acoust. Soc. Am., 101(4):213547, 1997.

Rohlf, F. J. TPSDig2, version 2.16. New York, Department of Ecology and Evolution, State University of New York at Stony Brook, 2010.

Roig, V. G. La hipertrofia de la bula timpánica y su significado adaptativo en los edentados de zonas áridas. Deserta, 2:87-97, 1971.

Schleich, C. E \& Busch, C. Functional morphology of the middle ear of Ctenomys talarum (Rodentia: Octodontidae). J. Mammal., 85(2):290$5,2004$.

Schleich, C. E. \& Vasallo A. I. Bullar volume in subterranean and surfacedwelling caviomorph rodents. J. Mammal., 84(1):185-9, 2003.

Segall, W. Further observations on the ear in fossorial mammals with special considerations of Chlamyphorus truncatus (Harlan). Acta Anat. (Basel), 94(3):431-44, 1976.

Squarcia, S. M.; Sidorkewicj, N. S. \& Casanave, E. B. The hypertrophy of the tympanic bulla in three species of dasypodids (Mammalia, Xenarthra) from Argentina. Int. J. Morphol., 25(3):597-602, 2007.

Webster, D. B. \& Plassmann, W. Parallel Evolution of Low Frequency Sensitivity in Old World and New World Desert Rodents. In: Webster, D. B.; Popper, A. N. \& Fay, R. R. (Eds.). The Evolutionary Biology of Hearing. New York, Springer-Verlag, 1992. pp.633-6.

Wible, J. R. \& Gaudin, T. J. On the cranial osteology of the yellow armadi1lo Euphractus sexcinctus (Dasypodidae, Xenarthra, Placentalia). Ann. Carnegie Mus., 73(3):117-96, 2004.

\author{
Corresponding author: \\ Dra. Nora S. Sidorkewicj \\ Prof. Adjunto Anatomía Comparada \\ Dpto. Biología, Bioquímica y Farmacia \\ Universidad Nacional del Sur \\ (8000) Bahía Blanca \\ ARGENTINA
}

Email: nsidorke@criba.edu.ar

Received: 08-11-2016

Accepted: 23-12-2016 